\title{
Desa Peduli Pendidikan Melalui Pendampingan Penulisan Karya Ilmiah (Laporan PTK)
}

\author{
Eko Purnomo*1, Kodrat Hi Karim² \\ ekop6990@gmail.com*1,kodrathkarim@gmail.com ${ }^{2}$ \\ 1,2Pendidikan Guru dan Sekolah Dasar, FKIP, Universitas Khairun
}

Received: 30 October 2021 Accepted: 06 December 2021 Online Publisher: 30 December 2021 DOI: 10.29408/ab.v2i2.4207

\begin{abstract}
Abstrak: Publikasi karya ilmiah menjadi salah satu unsur penting terhadap kenaikan pangkat pendidik. Permasalahannya adalah rata-rata guru di SD Negeri 45 belum mampu melakukan penulisan dan publikasi secara mandiri bahkan beberapa guru belum mahir dalam mengoperasikan komputer khususnya penggunaan Microsoft Office Word. Padahal penulisan karya ilmiah memerlukan keterampilan tersebut untuk mempermudah pekerjaan guru selama menulis. Pada pengabdian ini terdapat beberapa poin yang dilatih yaitu optimalisasi penggunaan Microsoft Office Word, kaidah penulisan laporan ilmiah dan publikasinya, serta teknik pelaksanaan PTK. Kegiatan ini dilaksanakan pada tanggal 18 September tahun 2021. Mitra pengabdian ini adalah seluruh guru di Sekolah Dasar Negeri 45 Kota Ternate. Metode yang digunakan adalah demonstrasi, ceramah dan tanya jawab. Hasil dari kegiatan pengabdian masyarakat menunjukkan guru di SD Negeri 45 Kota Ternate mampu menulis laporan ilmiah PTK meskipun hanya 3 orang yang memiliki kemampuan menulis paling baik. Pada tahap evaluasi ditemukan beberapa koreksi seperti kesalahan penulisan kata, teknik analisis data dan penggunaan referensi. Kendala dalam penelitian ini adalah keterbatasan laptop dan komputer sehingga membutuhkan waktu yang lama karena saat latihan fasilitas laptop yang tersedia adalah 3 sehingga guru dibagi dalam 3 kelompok belajar. Namun, secara keseluruhan pengabdian ini mampu memberikan pemahaman dan motivasi pada guru di SD Negeri 45 Kota Ternate untuk melakukan penulisan karya ilmiah.
\end{abstract}

Kata kunci: Kenaikan Pangkat Guru; Laporan Ilmiah; Penelitian Tindakan Kelas; Publikasi

\begin{abstract}
The publication of scientific papers is an essential element in promoting educators. The problem is that the average teacher at SD Negeri 45 has not written and published independently. Some teachers are not proficient in operating computers, especially Microsoft Office Word. Even though writing scientific papers requires these skills to facilitate the work of teachers during writing. In this service, several points are trained, namely optimizing the use of Microsoft Office Word, the rules of writing scientific reports and publications, and techniques for implementing CAR. This activity was carried out on September 18, 2021. The partners of this service were all teachers at the 45 Ternate State Elementary School. The method used is demonstration, lecture, and question and answer. The results of community service activities show that teachers at SD Negeri 45 Ternate City can write CAR scientific reports even though only three people have the best writing skills. At the evaluation stage, several corrections were found, such as spelling errors, data analysis techniques, and the use of references. The obstacle in this research is the limitations of laptops and computers. It takes a long time because there are three available laptop facilities during practice, so the teacher is divided into 3 study groups. However, overall, this service can provide understanding and motivation to teachers at SD Negeri 45 Ternate City to write scientific papers.
\end{abstract}

Keywords: Classroom Action Research; Publication; Scientific Reports; Teacher Promotion 
Purnomo, E., Karim, K. I. (2021). Desa Peduli Pendidikan melalui pendampingan penulisan Karya IImiah (laporan PTK). ABSYARA: Jurnal Pengabdian Pada Masyarakat, 2(2), 220-229. Doi: 10.29408/ab.v2i2.4207

\section{PENDAHULUAN}

Guru sebagai salah satu komponen penting yang memiliki peran untuk membimbing peserta didik, peran tersebut menuntut guru agar selalu melakukan mengembangkan profesionalitasnya (Risdiany, 2021). Berdasarkan penjelasan dalam Peraturan Pemerintah Republik Indonesia Nomor 74 Tahun 2008 guru sebagai tenaga profesional yang mempunyai visi terwujudnya penyelenggaraan pembelajaran sesuai dengan prinsip-prinsip profesionalitas. Dalam rangka perwujudan guru profesional, guru harus memenuhi kualifikasi akademik, kompetensi, sertifikat pendidik, sehat rohani dan jasmani, mampu memenuhi tugas dan tanggung jawab selama berada di tempat tugas dan mampu mewujudkan tujuan pendidikan nasional. Peningkatan kualitas dan pengembangan diri sangat diperlukan sehingga guru tetap prima dalam menjalankan tugasnya sebagai pendidik. Terdapat berbagai unsur penilaian guru profesional di antaranya pemberian sertifikat pendidikan dan kenaikan pangkat selama bertugas.

Berdasarkan Permenpan dan RB Nomor 16 Tahun 2009 tentang jabatan fungsional guru dan angka kreditnya bahwa salah satu unsur kegiatan pengembangan profesi adalah publikasi ilmiah. Guru profesional sepatutnya dapat memenuhi unsur-unsur tersebut. Sejak tahun 2013, pemerintah memberlakukan sistem angka kredit untuk kenaikan pangkat mulai dari golongan III b, hal ini diharapkan dapat memberikan apresiasi kepada guru yang telah menjalankan tugas secara profesional secara lebih adil sehingga dapat berdampak langsung pada kesejahteraan guru sesuai dengan kelayakannya (Daryanto, 2013). Selain itu, Publikasi karya ilmiah juga dapat menjadi langkah cerdas dalam pengembangan diri (Mawardi, dkk., 2019). Harapan pemerintah memberlakukan angka kredit agar mempermudah guru untuk kenaikan pangkat. Namun, faktanya sebagian besar guru belum mampu melakukan dan menghasilkan publikasi ilmiah (Sumarni, dkk., 2020). Kemampuan menulis artikel ilmiah di Indonesia bahkan dapat dikatakan masih rendah jika dibandingkan dengan negara lain. Hal ini dapat juga disebabkan adanya faktor waktu revisi artikel pada jurnal yang cukup lama dan motivasi menulis yang rendah akibatnya Sebagian guru harus bertahan dengan pangkat seadanya hingga menunggu masa pensiun (Wicaksana, dkk., 2021).

Permasalahan tersebut pun dialami oleh guru di SD Negeri 45 kota Ternate. Para guru kesulitan dalam melakukan publikasi ilmiah. Hal ini disebabkan karena kurangnya pemahaman guru tentang tata cara penulisan karya ilmiah. Rata-rata guru hanya menulis pada saat menempuh kuliah S1 (Sarjana) bahkan beberapa masih belum mahir dalam mengoperasikan Microsoft Office Word karena keterbatasan fasilitas berupa komputer/laptop. Supriyanto (2017) menyatakan bahwa penyebab rendahnya motivasi menulis karya ilmiah pada guru adalah (1) rendahnya pemahaman tentang teknik penulisan, (2) keterbatasan waktu akibat rutinitas di sekolah yang tinggi, (3) gagap teknologi dan (3) minat membaca yang rendah. Padahal, publikasi ilmiah merupakan salah satu unsur yang harus dipenuhi untuk kenaikan pangkat. Dalam rangka peningkatan kualitas guru maka diperlukan pelatihan dan pendampingan mengenai penulisan karya ilmiah.

Pada pengabdian ini, PTK (Penelitian Tindakan Kelas) dipilih berdasarkan permintaan mitra pengabdian. PTK merupakan salah satu metode yang dapat dilakukan secara bersamaan dengan proses belajar sehari-hari di kelas. PTK dapat diartikan sebagai sarana pemecahan masalah yang ditemukan guru untuk meningkatkan kualitas dari pembelajaran (Arikunto, 2008). Penelitian PTK dapat dimanfaatkan sebagai perencanaan kegiatan untuk mencapai 
tujuan secara praktis, pemecahan masalah yang timbul selama penerapan kurikulum, kegiatan inovasi pembelajaran dan terbukanya sarana diskusi yang terstruktur, bebas dan terbuka (Wiraatmadja, 2008). Pada pelaksanaan pembelajaran sehari-hari, guru-guru mitra PKM di sekolah SD Negeri 45 Kota Ternate sering melakukan tahapan PTK namun belum mampu dituliskan dalam bentuk laporan ilmiah sehingga pada pengabdian ini target yang ingin dicapai adalah guru dapat memahami dan melakukan penulisan karya ilmiah.

\section{METODE PELAKSANAAN}

\section{Waktu dan tempat}

Pengabdian ini dilaksanakan pada Tanggal 18 September Tahun 2021 di Sekolah Dasar Negeri 45 Kota Ternate yang terletak di Kelurahan Toboleu, Kecamatan Kota Ternate Utara Provinsi Maluku Utara.

\section{Prosedur pelaksanaan}

Pengabdian ini merupakan hasil telaah permasalahan mitra yang kesulitan dalam penulisan karya ilmiah sehingga rata-rata guru belum mampu melakukan publikasi Ilmiah. Mitra PKM terdiri dari seluruh guru di Sekolah Dasar Negeri 45 Kota Ternate berjumlah 13 orang. Berdasarkan analisis hasil wawancara permasalahan mitra PKM maka metode yang digunakan adalah demonstrasi dan ceramah. Prosedur pengabdian terdiri dari kegiatan pendahuluan, pendampingan, dan monitoring (Gambar 1).

\section{Pendahuluan}

(Perkenalan dan pemberian materi PTK)

\section{Pendampingan}

(praktik penulisan dan publikasi)

\section{Monitoring}

(pengawasan dan evaluasi

pekerjaan guru)

a. Pendahuluan

PTK atau penelitian tindakan kelas merupakan suatu tindakan perbaikan praktik mengajar yang kurang sesuai dalam rangka peningkatan kualitas guru (Ariawan \& Ruqaiyah, 2020). Penelitian tindakan kelas memiliki satu atau lebih siklus tergantung pada hasil dari pembelajaran yang telah berlangsung. kegiatan tersebut telah umum dilakukan oleh guru yang biasanya disebut REMEDIAL. Pada kegiatan pendahuluan, para guru diberikan materi tentang prinsip-prinsip PTK, tahapan PTK, teknik pelaksanaan PTK dan penulisan hasil penelitian PTK.

b. Pendampingan

Guru diajarkan untuk mempraktikkan teknik penulisan laporan PTK dengan dipandu oleh tim pelaksana PKM. Praktik penulisan dimulai dari cara penulisan latar belakang, perumusan masalah, penentuan metode, analisis data, pembahasan, penarikan kesimpulan dan teknik penulisan pustaka. Pendampingan publikasi dilakukan dengan dua cara yaitu teknik penentuan jurnal berdasarkan rangking dan cara submit artikel. Publikasi ini dicontohkan dengan menggunakan artikel yang telah disiapkan.

c. Monitoring

Pengawasan dan evaluasi guru dilakukan dengan dua cara yaitu online dan offline. Guru diwajibkan memiliki satu tulisan yang terpublikasi pasca pengabdian ini sehingga tim PKM 
selalu berusaha untuk membantu para guru dalam proses penulisannya. Evaluasi dilakukan pada tiap tahap yaitu tahap penulisan dan tahap publikasi. Hal ini bertujuan agar guru termotivasi untuk meningkatkan kualitas diri melalui penelitian.

\section{HASIL DAN PEMBAHASAN}

HASIL

Salah satu bentuk pengembangan profesi guru adalah membuat karya ilmiah dan mempublikasikannya. Guru sebagai profesi profesional diwajibkan memiliki berbagai kemampuan, salah satunya adalah menulis karya ilmiah. Hal tersebut digunakan menunjang karier dan bentuk penghargaan terhadap kinerja guru (Wahyuningtyas dan Ratnawati, 2018). Berdasarkan hasil analisis permasalahan mitra menunjukkan bahwa hanya terdapat dua guru dari 13 guru target pengabdian yang telah melakukan publikasi ilmiah meskipun belum mampu dilakukan secara mandiri melainkan dibantu oleh orang yang expert dalam hal publikasi ilmiah. Hal ini dilakukan guru karena terdesak untuk kenaikan pangkat. Permasalahan tersebut tim PKM merancang suatu pengabdian melalui pelatihan tentang teknik penulisan laporan ilmiah. PTK dipilih karena memiliki prosedur yang mirip dengan proses mengajar guru sehari-hari. Supriyanto (2017) menyatakan bahwa guru telah melaksanakan PTK namun belum dilakukan secara sistematis dan sesuai tahapan yang benar.

Kegiatan PKM melalui pelatihan dan pendampingan penulisan laporan ilmiah PTK memberikan kajian mengenai teknik pelaksanaan PTK yang benar sekaligus cara menuliskan dan mempublikasikannya pada laman artikel bereputasi Nasional. Hal ini cukup sulit dilakukan karena mitra PKM memiliki skill dalam mengoperasikan komputer serta pengetahuan tentang penulisan karya ilmiah yang sangat rendah. Padahal, kedua aspek tersebut paling dibutuhkan dalam menuliskan laporan ilmiah. Kusumaningrum, dkk., (2020) menyatakan salah satu penyebab rendahnya publikasi ilmiah pada guru adalah penguasaan terhadap wawasan penulisan artikel ilmiah. Selain itu, mitra PKM di SD Negeri 45 Kota Ternate juga belum pernah mendapatkan pelatihan atau pendampingan tentang penulisan laporan ilmiah PTK sehingga guru sangat antusias mengikuti semua rangkaian kegiatan yang ditargetkan (Gambar. 2).

Pengabdian ini diawali dengan tes kemampuan awal dalam mengoperasikan Microsoft Office Word, hasilnya menunjukkan terdapat lima guru yang cukup baik dalam mengoperasikan Microsoft Office Word sedangkan sebagian guru cukup kesulitan dalam mengetik dan menguasai beberapa tools misalnya untuk mengubah huruf pada suatu kata menjadi huruf kecil menjadi besar dalam satu kata masih dilakukan secara manual yaitu menghapus huruf yang akan diganti kemudian menyalakan tombol capslock. Padahal dapat dilakukan dengan teknik yang singkat yaitu shift $+F 3$. Penguasaan teknologi komputer maupun internet sangat dibutuhkan selama penyusunan karya ilmiah. Menurut hasil penelitian Widana, dkk., (2019) bahwa salah satu penyebab guru kesulitan melakukan penulisan karya ilmiah adalah rendahnya kemampuan IT pada guru. 


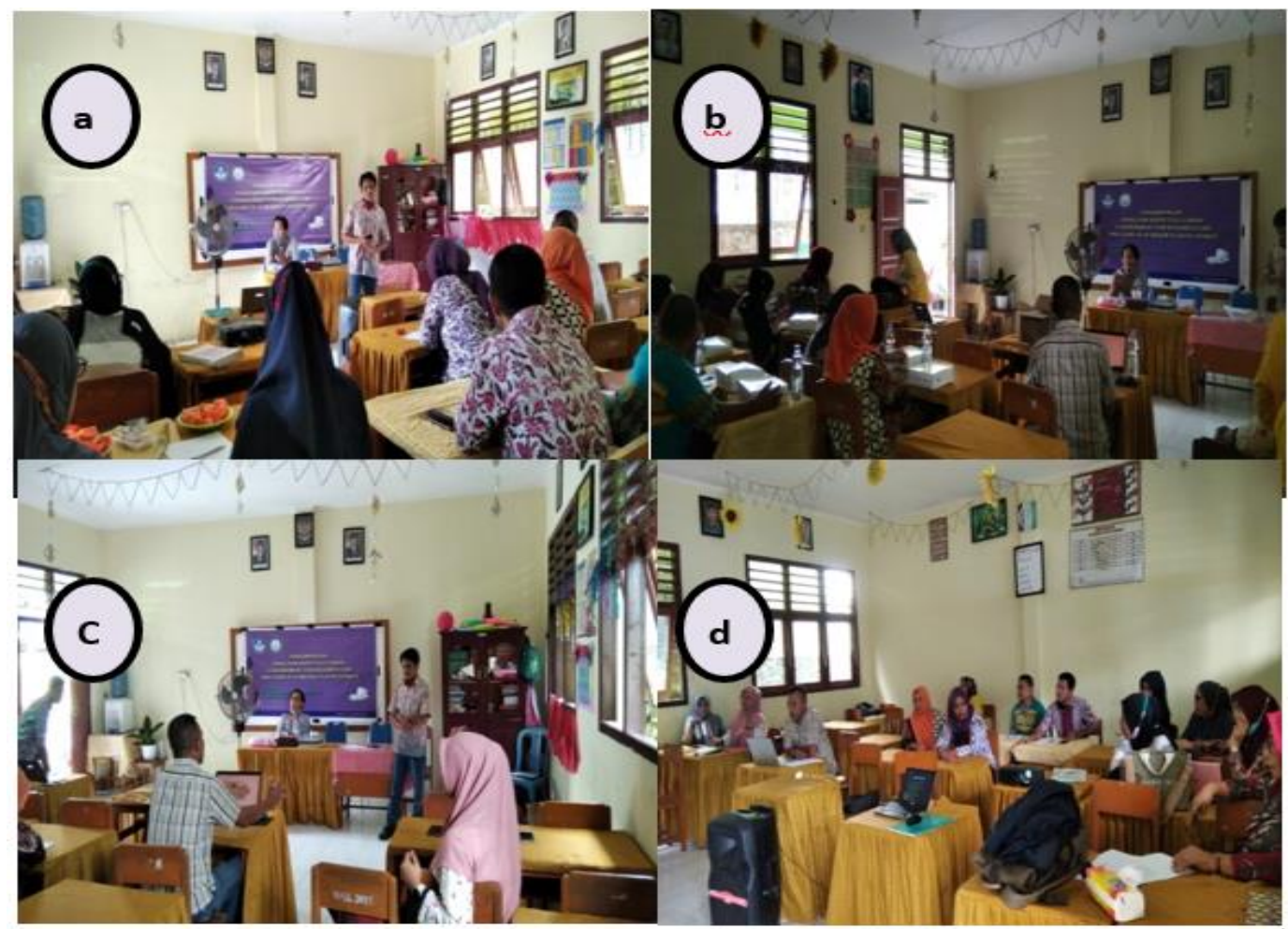

Gambar 2. Dokumentasi PKM tentang penulisan laporan ilmiah PTK

Pada tahap pendampingan penulisan karya ilmiah dilakukan dengan cara berkelompok. Hal ini disebabkan ketersediaan fasilitas komputer oleh mitra yang tidak mencukupi. Terdapat 3 laptop sehingga guru-guru dibagi dalam 3 kelompok (Gambar 2d). setiap kelompok diberikan kebebasan dalam menentukan permasalahan yang akan diangkat. Pada tahap ini, tiap kelompok diminta untuk menyusun latar belakang dan metode penelitian berdasarkan prosedur PTK. Hasil penulisan awal langsung dilakukan evaluasi.

Berdasarkan hasil evaluasi selama pendampingan dan pelatihan, guru-guru kesulitan dalam menentukan permasalahan yang dapat dikaji secara ilmiah serta cara penulisan alur permasalahan dalam bentuk latar belakang sehingga tim PKM melakukan pendampingan langsung pada masing-masing kelompok melalui diskusi langsung dalam kelompok. Hodiyanto \& Alimin (2020) menyatakan bahwa kegiatan pendampingan mampu meningkatkan keterampilan guru dalam menulis laporan ilmiah.

Permasalahan lain yang dihadapi adalah penulisan data hasil penelitian. Data hasil penelitian dituliskan secara langsung tanpa dianalisis menggunakan rumus persentase terhadap hasil belajar siswa pada siklus 1 dan 2 (Gambar 3). Hal ini memungkinkan, pembaca kesulitan dalam menginterpretasikan data hasil penelitian. Kesalahan lain yang ditemukan adalah guru melakukan prosedur yang keliru pada siklus 2 yaitu melewatkan tahap evaluasi kegiatan pembelajaran sehingga deskripsi kegiatan siklus 1 dan 2 sama. Kekeliruan tersebut direvisi dan diberikan pemahaman tambahan mengenai tahapan PTK oleh tim PKM. Supriyanto (2017) menyatakan bahwa penguasaan PTK pada guru dapat berdampak pada kualitas pembelajaran dan memberikan pengaruh langsung terhadap kualitas pendidikan. 


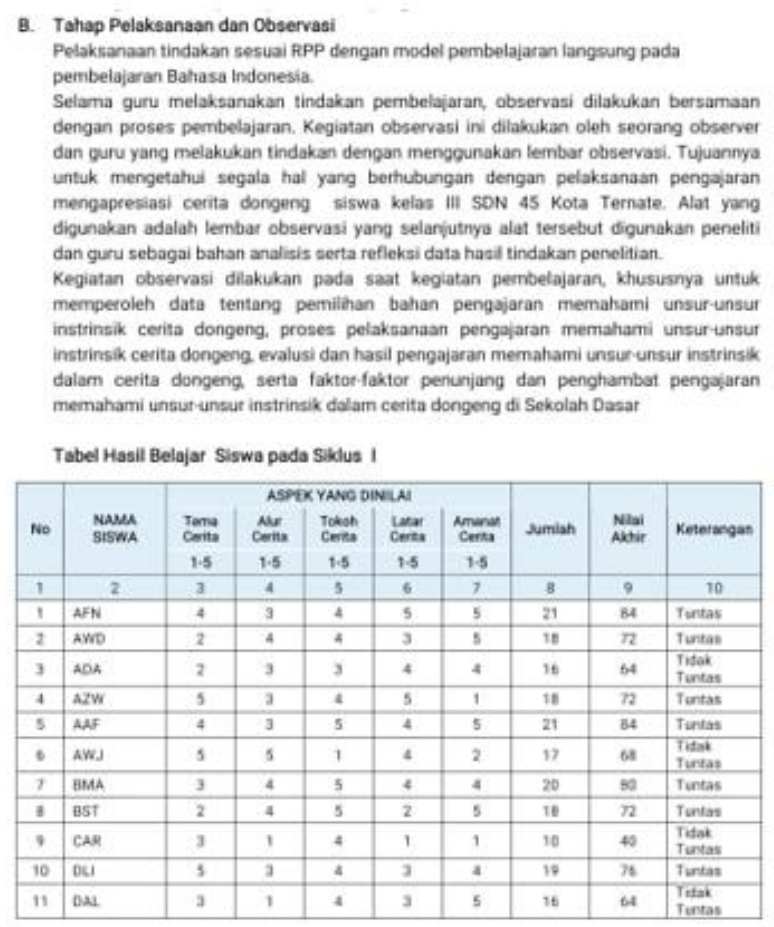

Gambar 3. Hasil karya ilmiah kelompok 4

Kesulitan lain adalah pencarian referensi yang akurat yang dapat dijadikan bahan untuk pembahasan sehingga para guru diajarkan cara mencari referensi yang sesuai dengan judul yang dibahas yaitu menggunakan Google Scholar (Gambar 4). Di sisi lain, para guru juga diminta memperhatikan jurnal-jurnal yang terdapat pada Google Scholar untuk dijadikan target publikasi yang sesuai dengan judul yang diteliti.

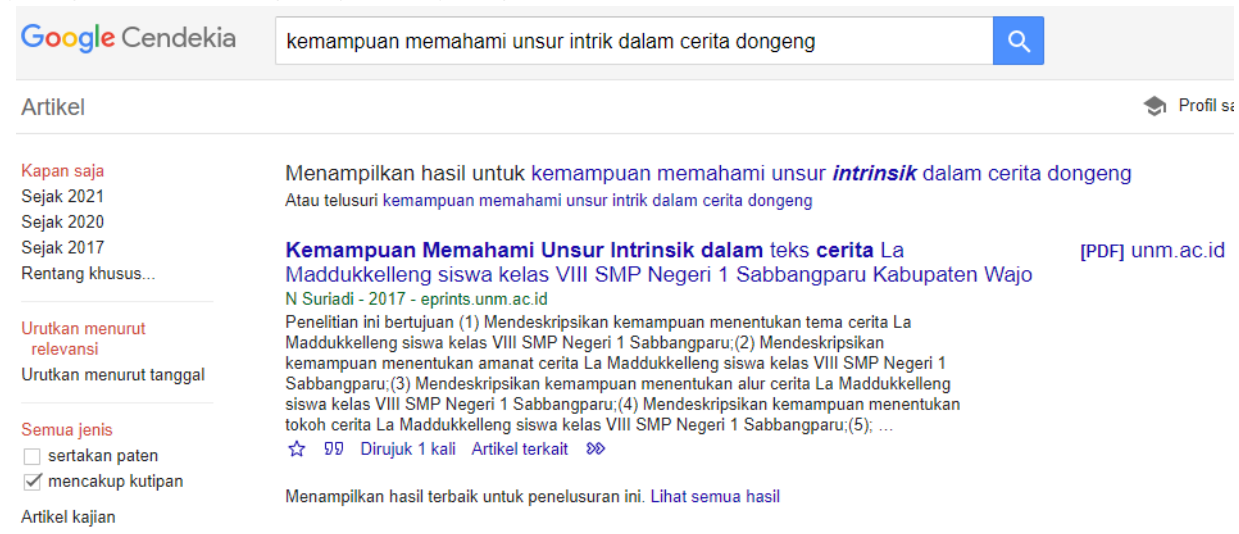

Gambar 4. Cara pencarian referensi melalui Google Scholar/Cendekia

\section{PEMBAHASAN}

Guru sebagai tenaga profesional dengan berbagai peran yang melekat yaitu pembelajar, asesor, manajer, model dan mengevaluasi (Aniuranti, dkk., 2021). Berdasarkan UndangUndang RI Nomor 14 Tahun 2005 menyatakan bahwa guru mempunyai kedudukan sebagai tenaga profesional berfungsi untuk meningkatkan martabat dan peran guru sebagai agen pembelajaran bertujuan untuk meningkatkan mutu pendidikan nasional. Guru sebagai komponen penting yang memiliki peran dinamis sebagai pelaksana terdapat di tingkat satuan 
pendidikan sehingga dalam rangka peningkatan mutu pendidikan, profesionalitas guru menjadi suatu keharusan (Kusumaningrum, dkk., 2020). Peningkatan mutu pendidikan merupakan tanggung jawab bersama antara pemerintah, masyarakat dan stakeholder yang terkait (Ain \& Mustika, 2021). Salah satu cara untuk memfasilitasi peningkatan mutu Pendidikan adalah mengadakan pelatihan kepada guru. Secara pragmatis, dapat dikatakan pelatihan memberikan dampak positif pada peserta latihan (Aniuranti, dkk., 2021).

Pendampingan dan pelatihan diberikan pada mitra pengabdian yang terdiri dari 13 orang guru. Masing-masing guru memiliki kompetensi tertentu. Untuk mengetahuinya, guruguru diberikan tes awal tentang pengetahuan dasar yang berkaitan dengan penulisan karya ilmiah, di antaranya adalah pengetahuan tentang IT, khususnya pada pengoperasian Office Word dan pemahaman tentang browsing internet. Sedangkan, pada bidang PTK guru diberikan pertanyaan seputar prosedur dan teknik pelaksanaan PTK. Hasilnya pemahaman guru rendah pada kedua kompetensi yang diujikan. Guru juga menjelaskan bahwa belum pernah mengikuti pelatihan penulisan karya ilmiah. Padahal pelatihan yang berkala oleh narasumber yang ahli dapat memberikan pemahaman yang jelas mengenai penulisan karya ilmiah (Noorjannah, 2014).

Pada tahap pendampingan guru diberikan dasar-dasar tentang Microsoft Office Word yang diperkirakan sering digunakan selama penulisan karya ilmiah berlangsung. materi kedua yaitu tentang teknik penulisan karya ilmiah diawali dengan cara penentuan judul yang menarik, prasyarat jumlah kata dalam judul, fungsi dan cara penulisan nama author, teknik penulisan abstrak, cara penyusunan latar belakang dan tujuan, metode PTK, teknik pengutipan, teknik analisis data dan pembahasannya serta penarikan kesimpulan dan penulisan daftar pustaka. Kemampuan menulis guru merupakan salah satu bentuk komunikasi gagasan yang dituangkan dalam bentuk tulisan, tidak mudah untuk menjadi ahli dalam menulis sehingga diperlukan keterampilan, latihan secara terus-menerus dan penguasaan terhadap aturan-aturan dalam penulisan (Widana, dkk., 2019).

Desain penelitian dengan cara PTK memiliki kemudahan dan kerumitan tersendiri. Ariawan \& Ruqaiyah (2020) menyatakan bahwa $75 \%$ guru tidak memahami implementasi PTK. Permasalahan yang terjadi pada mitra PKM guru masih kaku dalam menjalankan PTK secara prosedur yang benar. Hal ini diduga karena rendahnya pemahaman tentang PTK. Kerumitan yang dialami oleh mitra PKM pada tiap kelompok adalah pengulangan materi jika terdapat siswa yang belum mencapai KKM dari mata pelajaran yang diujikan karena akan bersinggungan dengan materi lain sehingga perlu pengaturan waktu yang ekstra. Sedangkan, kemudahan yang disampaikan para guru bahwa desain penelitian ini telah dilakukan setiap hari sehingga cukup mudah untuk dipelajari.

Salah satu kendala pada pengabdian ini adalah minimnya fasilitas laptop/komputer sehingga guru-guru dibagi dalam tiga kelompok disesuaikan dengan jumlah laptop yang tersedia (Gambar 2d). Setiap kelompok diberikan kesempatan untuk menentukan permasalahan yang diangkat dan merumuskannya dalam sebuah judul penelitian. Setiap kelompok ditugaskan untuk menyusun pendahuluan sampai dengan hasil penelitiannya. Berdasarkan hasil awal yang dipaparkan dalam persentase masing-masing kelompok, hasil pemaparan awal dari seluruh kelompok cukup baik dalam penyusunan rancangan laporan ilmiah PTK. Hal ini diduga karena dikerjakan dalam kelompok. Kelemahannya tim PKM masih belum mampu mendeteksi kemampuan setiap guru secara individu. Namun hal ini dapat dijadikan awal yang 
baik untuk pengembangan profesi guru. Kegiatan pelatihan ini dapat menjadi motivasi bagi guru untuk melakukan penulisan karya ilmiah sebagai bentuk peningkatan profesionalisme (Noorjannah, 2014).

Pada tahap monitoring dilakukan dengan dua cara yaitu online menggunakan Whatsapp dan secara tatap muka. Berdasarkan laporan hasil dari kelompok ditemukan terdapat kelompok yang kesulitan dalam memaparkan hasil penelitiannya sehingga data hasil penelitian dituliskan langsung dalam tulisan tanpa dianalisis (Gambar 3). Koreksi yang disampaikan adalah melakukan revisi sesuai dengan teknik analisis data PTK yang telah diajarkan. Hasil wawancara dengan anggota kelompok bahwa guru-guru kesulitan dalam perhitungan persentase kelulusan siswa dan cara mentransformasikan dalam bentuk grafik yang sederhana dan informatif. Kesulitan ini diatasi dengan cara mengirimkan contoh pemaparan data dari metode PTK.

Berdasarkan hasil revisi yang telah dilaksanakan tiap kelompok, penulisan karya ilmiah yang dilakukan berkelompok cukup baik jika dibandingkan dengan revisi pertama. Namun, hal ini tidak berarti tulisan para guru telah memuaskan mengingat tulisan tersebut masih akan direvisi oleh para reviewer dari jurnal yang dituju. Motivasi untuk tetap serius dalam mengembangkan diri terutama dalam melakukan penulisan karya ilmiah yang sesuai dengan kaidah dan mempublikasikannya merupakan bentuk profesionalitas guru dalam rangka meningkatkan kualitas diri sebagai pendidik demi terwujudnya tujuan pendidikan nasional.

Pengabdian ini dapat dikatakan sukses karena guru-guru termotivasi untuk menulis. Guru-guru juga mendapatkan pemahaman tentang IT dan kaidah-kaidah penulisan laporan ilmiah PTK. Pada dasarnya guru-guru mitra PKM memiliki kemampuan untuk menulis dan publikasi karya ilmiah namun terdapat kendala yang menyebabkan hilangnya motivasi untuk menulis. Rintaningrum (2018) menyatakan penyebab guru tidak melakukan kewajiban menulis artikel ilmiah adalah (a) beban kerja mengajar, (b) keterbatasan ide, (c) motivasi rendah, (d) minimnya literatur, dan (e) revisi yang berulang kali yang menyita waktu.

\section{SIMPULAN}

Pelaksanaan pengabdian dan pelatihan penulisan karya ilmiah (laporan PTK) merupakan bentuk dari penanganan permasalahan yang dihadapi oleh mitra pengabdian di SD Negeri 45 Kota Ternate. Pengabdian ini mampu memberikan pemahaman dan motivasi pada guru tentang teknik penulisan laporan ilmiah PTK. Guru mampu membuat tulisan karya ilmiah meskipun masih terdapat koreksi pada hasil karya yang dibuat berkelompok. Pengabdian ini diharapkan menjadi langkah awal yang strategis bagi seluruh guru untuk mengembangkan potensinya dalam melakukan dan mempublikasikan karya ilmiah. Salah satu metode yang disarankan adalah PTK. Adapun segala kekurangan yang belum terkoreksi dapat dikembangkan melalui diskusi ataupun pelatihan lain yang terkait sehingga guru-guru dapat meningkatkan potensinya sebagai bentuk profesionalitas sekaligus peningkatan kesejahteraan sosial ekonomi.

\section{PERNYATAAN PENULIS}

Artikel pengabdian kepada masyarakat yang didanai oleh Universitas Khairun dengan judul "Desa Peduli Pendidikan melalui Pendampingan Penulisan Karya Ilmiah (Laporan 
Purnomo, E., Karim, K. I. (2021). Desa Peduli Pendidikan melalui pendampingan penulisan Karya Ilmiah (laporan PTK). ABSYARA: Jurnal Pengabdian Pada Masyarakat, 2(2), 220-229. Doi: 10.29408/ab.v2i2.4207

PTK)" merupakan kegiatan yang benar-benar dilaksanakan oleh penulis dan belum pernah dipublikasikan di mana pun.

\section{DAFTAR PUSTAKA}

Ain, S. Q., \& Mustika, D. (2021). Pelatihan Pembuatan Media Pembelajaran Matematika kepada Guru Sekolah Dasar. Jurnal Abdidas, 2(5), 1080-1085.

Aniuranti, A., Tsani, M. H. N., \& Wulandari, Y. (2021). Pelatihan penyusunan Ice Breaking untuk penguatan kompetensi calon guru. ABSYARA: Jurnal Pengabdian Pada Masyarakat, 2(1), 85-93.

Ariawan, R., \& Ruqaiyah, R. (2020). Pelatihan Penulisan Karya Ilmiah (Penelitian Tindakan Kelas) Bagi Guru-Guru SD. Community Education Engagement Journal, 1(2), 73-82.

Arinkunto, S. (2002). Prosedur penelitian suatu pendekatan praktek. Jakarta: PT Rineka Cipta.

Daryanto. 2013. Standar Kompetensi dan Penilaian Kinerja Guru Profesional. Yogyakarta: Gaya Media.

Departemen Pendidikan Nasional, 2005. Undang-Undang Republik Indonesia, Nomor 14 Tahun 2015 Tentang Guru dan Dosen. Depdiknas RI: Jakarta.

Hodiyanto, H., \& Alimin, A. A. (2020). In House Training (IHT) dalam penyusunan karya tulis ilmiah. ABSYARA: Jurnal Pengabdian Pada Masyarakat, 1(2), 56-63.

Kusumaningrum, D. E., Sumarsono, R. B., \& Gunawan, I. (2020). Pendampingan Penulisan Karya Ilmiah Melalui Pendekatan Clinical Coaching bagi Guru Madrasah Inklusi. Abdimas Pedagogi: Jurnal Ilmiah Pengabdian kepada Masyarakat, 3(1), 2331.

Mawardi, M., Kristin, F., Anugraheni, I., \& Rahayu, T. S. (2019). Penerapan Pelatihan Partisipatif Pada Kegiatan Penulisan Dan Publikasi Karya Ilmiah Bagi Guru SD. Scholaria: Jurnal Pendidikan Dan Kebudayaan, 9(2), 132-137.

Noorjannah, L. (2014). Pengembangan profesionalisme guru melalui penulisan karya tulis ilmiah bagi guru profesional di SMA Negeri 1 Kauman Kabupaten Tulungagung. Jurnal Humanity, 10(1), 97-104.

Rintaningrum, R. (2015). Mengapa Guru Tidak Menulis Karya Ilmiah: Perspektif Guru. In Seminar Nasional 'Bahasa, Sastra, dan Pendidikan Dalam Perspektif Masyarakat Ekonomi ASEAN.

Risdiany, H. (2021). Pengembangan Profesionalisme Guru Dalam Mewujudkan Kualitas Pendidikan di Indonesia. AL-HIKMAH (Jurnal Pendidikan dan Pendidikan Agama Islam), 3(2), 194-202.

Sumarni, S., Prayitno, A. T., \& Adiastuty, N. (2020). Pendampingan Penulisan Artikel Ilmiah Bagi Guru-Guru SMA Kecamatan Jalaksana Kabupaten Kuningan. Al-Khidmat : Jurnal Ilmiah Pengabdian Kepada Masyarakat, 3(1), 15-24. 
Supriyanto, A. (2017). Peningkatan kemampuan guru dalam penulisan karya ilmiah melalui pelatihan penelitian tindakan kelas. Abdimas Pedagogi: Jurnal Ilmiah Pengabdian kepada Masyarakat, 1(1), 1-7.

Wahyuningtyas, N., \& Ratnawati, N. (2018). Pelatihan dan Pendampingan Penulisan Artikel Jurnal bagi Guru-Guru IPS Kabupaten Malang. Jurnal Praksis dan Dedikasi Sosial $(J P D S), 1(1), 40-47$.

Wicaksana, M. F., Suparmin, S., Sudiatmi, T., \& Muryati, S. (2021). Pendampingan peningkatan profesionalitas guru Bahasa Indonesia melalui literasi menulis artikel di jurnal ilmiah. ABSYARA: Jurnal Pengabdian Pada Masyarakat, 2(1), 128-136.

Widana, I. W., Suarta, I. M., \& Citrawan, I. W. (2019). Penerapan metode simpang tegar untuk meningkatkan kemampuan guru dalam penulisan PTK dan artikel ilmiah. JPM (Jurnal Pemberdayaan Masyarakat), 4(1), 365-375.

Wiraatmadja, R. (2012). Metode Penelitian Tindakan Kelas (Untuk Meningkatkan Kinerja Guru dan Dosen). Bandung: Remaja Rosdakarya. 